Fountain Journal of Natural and Applied Sciences 2018; 7(1): 20-28
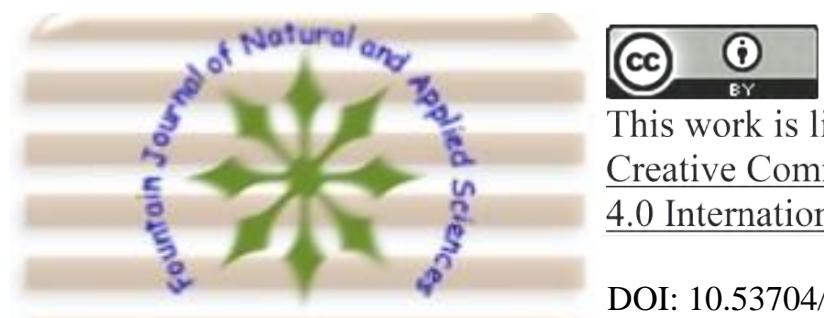

This work is licensed under

Creative Commons Attribution

4.0 International License.

DOI: 10.53704/fujnas.v7i1.166

A publication of College of Natural and Applied Sciences, Fountain University, Osogbo, Nigeria.

Journal homepage: www. fountainjournals.com

ISSN:2354-337X(Online),2350-1863(Print)

\title{
Antidiarrhoeal Activities of Ethanolic Extract of Aristolochia ringens Stem Bark in Castor Oil-Induced Diarrhoeal Albino Rats
}

\author{
Bamisaye, F. A., Sulyman, A. O., ' Ibrahim, R. B. and Yusuf, B. L. \\ Department of Biochemistry, Kwara State University, Malete, Ilorin, Nigeria
}

\begin{abstract}
The antidiarrhoeal potentials of ethanolic extract of Aristolochia ringens stem back was evaluated in castor oil-induced diarrhoeal rats. The $A$. ringens stem back ethanolic extract was, in addition, screened for its phytoconstituents. Thirty albino rats of 150-180 $\mathrm{g}$ were randomized into six groups of five animals each for each of the three experiments and all administration were oral. Rats in groups I and II were administered $1.0 \mathrm{ml}$ distilled water and 1\% DMSO (Vehicle) respectively, while those in group III were administered 2.5 $\mathrm{mg} / \mathrm{kg}$ b.wt loperamide hydrochloride as reference drug. Rats in groups IV, V and VI were administered 25, 50 , and $100 \mathrm{mg} / \mathrm{kg}$ b.wt. ethanolic extract of A. ringens stem bark. The castor oil-induced diarrhoeal model was used, the weight and volume of the intestinal content was determined by enteropooling method and the intestinal motility was determined using activated charcoal method. The small intestine of the rats was also assessed for histopathological changes. The extract significantly and dose-dependently reduced the number of diarrhoeal faeces, the volume of intestinal accumulation and the distance moved by the fed charcoal in treated rats compared to the untreated diarrhoeal group (group II). The percentage inhibitions exhibited by the extract at 50 and $100 \mathrm{mg} / \mathrm{kg}$ body weight were significantly higher than that of the reference drug. Furthermore, the photomicrograph of the intestine of the extract treated rats showed intact intestinal architecture. Hence, ethanolic extract of Aristolochia ringens stem bark may contain phytochemicals with better antidiarrhoeal potentials which can be explored in the development of more viable antidiarrhoeal agents.
\end{abstract}

Keywords: Aristolochia ringens, Antidiarrhoeal agents, Intestinal motility, Intestinal accumulation

\section{Introduction}

Diarrhoea is a gastrointestinal disorder that results from alterations in the normal bowel movement leading to increase in the water content of the intestine and/or frequency of stools (Guarrant et al., 2001) as well as severe dehydration that can become life-threatening when not treated (Alam and Ashraf, 2003). Epidemiological and experimental evidences for the alarming world prevalence of diarrhoea still remain disturbing despite significant reduction due to awareness, especially in children. It is regarded as the first runner-up killer of children under 5 years of age, which accounts for $10 \%$ of child deaths every year (Liu et al., 2012), and leading cause of malnutrition and death among children in many

*Corresponding author: +2347036443271

Email address: ibrahimrasheedb@gmail.com 
countries. This is more important in the developing countries where malnutrition is concurrently an important public health concern, especially among infants. Generally, low and lower-middle income countries, Nigeria inclusive, are home to 62 per cent of the world's under 5 population, but account for more than 90 per cent of global diarrhoeal deaths (UNICEF, 2016).

Although there are drugs available for the treatment of diarrhoea, population rise, inadequate supply of drugs, prohibitive cost of treatments, and side effects of several allopathic drugs (Joy et al., 2001) call for alternatives. Some of such alternatives used in the treatment of diarrhoea are Psidium guajava (Njume et al., 2011), Conyza dioscoridis (Ojewale et al., 2008) and Carica papaya (Tona et al., 1999). One of the many alternatives of local plants used for the treatment of diarrhoea in Nigeria is Aristolochia ringens, which is known with the common name Gaping Dutchman's pipe (pipe vine) (Minari and Idris, 2015).

Aristolochia ringens (Vahl.) is a tall, hairless, slender, bushy climber with stalked leaves, round, almost kidney shaped, pale green above and glaucous beneath. It is native to tropical America and introduced to most West African countries such as Sierra Leone and Nigeria, where it is used in traditional medicine for the management of rheumatoid arthritis, diarrhoea, snake bites and asthma (Olabanji et al., 2008). They are commonly found in the south-western part of Nigeria (NNMDA, 2008), with the local name 'Akoogun' or 'Awo igba arun oyo' (Minari and Idris, 2015). Aristolocchia ringens has been screened and confirmed to possess some of its acclaimed ethnobotanical properties such as anti-diabetic activity (Sulyman et al., 2016) and anti-inflammatory activity (Aigbe et al., 2014), and thus the medicinal importance of its essential oil, aristolochic acid and other phytochemicals isolated from its root and stem has been severally ascertained (Fasola et al., 2015).

However, the acclaimed beneficial role of the plant in diarrhoea is yet to be screened let alone ascertained, hence this research was designed to evaluate the anti-diarrhoeal potentials of the ethanolic extract of Aristolochia ringens stem bark in castor oil-induced diarrhoeal Albino rats.

\section{Materials and Methods \\ Materials \\ Plant Material}

Aristolochia ringens was obtained from Alanamu Market, Ilorin West Local Government Area of Kwara State, Nigeria. Authentication of the sample was carried out at the Harbarium of Department of Botany, Lagos State University, Ojo, Lagos State, Nigeria where a voucher specimen (LUH 6234) was deposited.

\section{Chemicals and Reagents}

Castor oil, loperamide, activated charcoal, gum arabic, ferric chloride, acetic acid, sodium chloride, hydrochloric acid, benzene, ammonia solution, Mayer's reagent, dimethyl sulfoxide, chloroform, diethyl ether, formalin were products of $B D H$ Chemicals Limited, Poole, Dorset, England. All other chemicals used in the research were of analytical grade.

\section{Experimental Animals}

A total of ninety (thirty used for each of enteropooling, intestinal transit and diarrheal stool experiments) albino rats of both sexes weighing between 150-180 g were obtained from the Animal Holding Unit of the School of Basic Medical Sciences, Kwara State University, Malete, Nigeria and kept in metallic cages placed in well ventilated house condition, at room temperature, photoperiod of 12 hours natural light and 12 hours dark and humidity $45-50 \%$ at the Animal House of the Department of Biochemistry, Kwara State University, Malete, Nigeria for two weeks to acclimatize them prior to commencement of treatments. They were given food and water ad libitum. The cleaning of the cages was done daily.

The research conformed strictly to the Principles of Laboratory Animal Care (NIH, 1996). The research protocols were approved by the Department of Biochemistry, Kwara State University, Malete, Kwara State in 2016.

\section{Preparation of extract}

Stem barks of Aristolochia ringens were washed with distilled water to ensure they are cleaned of dirt and air dried at room temperature for 2 weeks. 
The dried stem barks were pulverized with an electric blender and $400 \mathrm{~g}$ of the resulting powder was extracted in $1000 \mathrm{ml}$ of absolute ethanol for 48 hours with manual intermittent shaking. The extraction mixture was then filtered using Whatman filter paper. The filtrate was concentrated and dried at $40{ }^{\circ} \mathrm{C}$ in dry oven (Searchtech Instruments DHG9101-1SA Dry Oven).

\section{Screening for the presence of Secondary Metabolites}

The procedures explained by Njoku and Obi (2009) was used for the detection of the secondary metabolites constituents in the Aristolochia ringen stem bark ethanolic extract.

\section{Castor oil-induced diarrhoea in rats}

Diarrhoea was induced in the rats using the method described by Gerald et al. (2007). The animals were fasted for 18 hours but were allowed free access to water. Groups I, II and III were orally administered $1 \mathrm{ml}$ of distilled water, DMSO and loperamide (2.5 $\mathrm{mg} / \mathrm{kg}$ body weight) respectively. Groups IV, V and VI were orally administered ethanolic extract at doses of $25,50,100 \mathrm{mg} / \mathrm{kg}$ body weight respectively. After 30 minutes of treatment with drug and extract, each animal in all groups (except the normal control group) was orally administered $1 \mathrm{ml}$ of castor oil. The time between oil administration and appearance of the first diarrhoeal drops was noted. Observations for determining the severity of diarrhoea were assessed for a period of 6 hours by monitoring the diarrhoeal drops. The total number of faeces, diarrhoeal faeces and the total weight of faeces excreted were expressed as an average and compared with those of the control groups. The percentage inhibition of diarrhoeal defaecation in each group was also calculated using the formula.

$\%$ inhibition $=$ TCF-TDF/ TCF $\times 100$

Where: $T C F=$ Total number of faeces in control group

TDF = Total number of diarrhoeal faeces in treated group

\section{Evaluation of anti-enteropooling activity of ethanolic extract of Aristolochia ringens stem barks}

Intraluminal fluid accumulation was determined as described by Havagiray et al. (2004). The test animals were fasted for 18 hours prior to the experiment and were allowed free access to water. Thirty animals were randomized into six groups of five animals each. Groups I, II and III were orally administered $1 \mathrm{ml}$ of distilled water, DMSO and loperamide $(2.5 \mathrm{mg} / \mathrm{kg}$ body weight) respectively. The test groups (III, IV and V) were administered the extract at the doses of 25,50 and $100 \mathrm{mg} / \mathrm{kg}$ body weight respectively. This was immediately followed with $1 \mathrm{ml}$ of castor oil in all the groups. After 60 minutes of administration, the animals were sacrificed under ether anaesthesia and the small intestines were removed and tied at the ends (pylorus and the caecum). The organ was dissected and the content was squeezed into a measuring cylinder. The volume and the weight of the intestinal content were determined.

\section{Gastrointestinal motility in castor oil-induced diarrhoeal rats}

For the experiment of small intestinal transit, the procedure was based on the method earlier described by Gerald et al. (2007). The animals were fasted for 18 hours prior to the experiment, but were allowed access to water. Each group contained five animals; Groups I, II and III were orally administered $1 \mathrm{ml}$ of distilled water, DMSO and loperamide (2.5 mg/kg body weight) respectively. The test groups IV, V and VI received the extract at doses of 25, 50 and $100 \mathrm{mg} / \mathrm{kg}$ body weight respectively. After 30 minutes, all the test animals were orally administered $1.0 \mathrm{ml}$ of charcoal meal $(10 \%$ $(w / v)$ charcoal suspension in $5 \%$ agar-agar). At 60 minutes post administration of the charcoal meal, all animals were sacrificed under ether anaesthesia and the small intestines (pylorus to caecum) were removed and the length as well as the distance moved by the charcoal meal through the organ were determined as follows:

$\%$ charcoal motility inhibition =

(Mean distance in control group - Mean distance in treated group) $\times 100$

Mean distance in control group

Histological examination of the small intestine

A specimen of the small intestine of each of the experimental group was fixed in $10 \%$ formalin. The 
specimens were dehydrated in ascending grades of ethanol, cleared in xylene, and processed to molten paraffin wax blocks, sectioned (5 $\mu \mathrm{m}$ thick) and stained with Haematoxylin and Eosin stain. They were then examined using light microscopy for observation of pathological changes due to castor oil-induced gastrointestinal dysfunctions and the treatment with Aristolochia ringens (Krause, 2001).

\section{Statistical Analysis}

The results were expressed as mean \pm Standard error of mean (SEM) of five replicates $(n=5)$. Data obtained were subjected to one-way analysis of variance and means found to be significantly different at $P<0.05$ were separated by Duncan's Multiple Range Test.

\section{Results}

Phytochemical analysis of ethanolic extract of Aristolochia ringens stem barks revealed the presence of alkaloids, tannins, flavonoids, cardiac glycosides and phenolics, while saponins and steroids were not detected (Table 1).

Forty-five minutes after the administration of castor oil, diarrhoea was clinically apparent in the animals in the untreated control group (group II). This was inferred from the appearance of diarrhoeal faeces which continued throughout the experimental period. Diarrhoea was inhibited (50\%) by $2.5 \mathrm{mg} / \mathrm{kg}$ body weight of orally administered loperamide. This is evident in the significant $(p<0.05)$ reduction in the total number of diarrhoeal faeces compared to the untreated control (group II). The ethanolic extract of Aristolochia ringens also dose-dependently reduced the total number of faeces and the total number of diarrhoeal faeces. At $25 \mathrm{mg} / \mathrm{kg}$ body weight the extract reduced diarrhoea to such that was comparable with the loperamide treated group while at 50 and $100 \mathrm{mg} / \mathrm{kg}$ b. wt, the extracts effected a significantly $(p<0.05)$ reduced diarrhoea compared with even the loperamide treated group. Thus the 25, 50 and $100 \mathrm{mg} / \mathrm{kg}$ body weight doses of A. ringens exhibited percentage inhibition of $58.3 \%$, $88.3 \%$ and $90.0 \%$ respectively (Table 2 ).
The castor oil-induced increase in the volume and weight of intestinal content was significantly ( $p$ < 0.05 ) and dose-dependently reduced by treatment with the ethanolic extract of $A$. ringens compared with untreated control group. The extract demonstrated percentage reductions of $32.5 \%$, $42.5 \%$ and $61.3 \%$ at 25,50 and $100 \mathrm{mg} / \mathrm{kg} \mathrm{b.} \mathrm{wt,}$ respectively (Table 3 ).

Also, the castor oil-induced increase in intestinal transit was significantly ( $p<0.05)$ reduced by both loperamide and the ethanolic extract of $A$. ringens stem barks at all the doses used (Table 4). Noteworthy is the fact that the dose of $100 \mathrm{mg} / \mathrm{kg}$ body weight of the extract performed better than loperamide

Photomicrographs of the small intestine of all the groups revealed normal cellular architecture of various tunics of the small intestine (Plate 1). Plate I shows the normal lamina propria and muscularis mucosal cells of the normal control group. Plates II and III show intact serosa and submucosa cells of DMSO and loperamide groups respectively. Plates IV, $V$ and VI show intact submucosa and muscularis mucosa cells of the small intestine of 25,50 and 100 $\mathrm{mg} / \mathrm{k}$ body weight $A$. ringens-treated animals.

Table 1: Secondary metabolite constituents of ethanolic extract of Aristolochia ringens stem bark

\begin{tabular}{ll}
\hline Phytochemicals & Remark \\
\hline Alkaloids & + \\
Tannins & + \\
Flavonoids & + \\
Saponins & - \\
Cardiac glycosides & + \\
Steroids & - \\
Phenolics & +
\end{tabular}

(+): Detected $\quad(-)$ : Not Detected 
Fountain Journal of Natural and Applied Sciences 2018; 7(1): 20-28

Table 2: Effect of ethanolic extract of Aristolochia ringens stem bark on castor oil-induced diarrhoeal rats

\begin{tabular}{lllll}
\hline Group & Treatment & $\begin{array}{l}\text { Total number } \\
\text { of faeces }(n)\end{array}$ & $\begin{array}{l}\text { Total number } \\
\text { of } \\
\text { faeces }(n)\end{array}$ & $\begin{array}{l}\text { Percentage } \\
\text { inhibition }\end{array}$ \\
\hline I & Distilled water $(1 \mathrm{ml})$ & $11.67 \pm 1.73^{\mathrm{ab}}$ & $0.00 \pm 0.00$ & -- \\
II & DMSO $(1 \mathrm{ml})$ & $16.00 \pm 4.20^{a}$ & $10.00 \pm 3.62^{a}$ & -- \\
III & Loperamide $(2.5 \mathrm{mg} / \mathrm{kg})$ & $11.33 \pm 1.61^{\mathrm{ab}}$ & $4.33 \pm 1.20^{\mathrm{b}}$ & 50.0 \\
IV & $25 \mathrm{mg} / \mathrm{kg}$ & $9.17 \pm 2.44^{\mathrm{abc}}$ & $4.17 \pm 0.91^{\mathrm{b}}$ & 58.3 \\
V & $50 \mathrm{mg} / \mathrm{kg}$ & $4.50 \pm 2.08^{c}$ & $1.17 \pm 0.40^{c}$ & 88.3 \\
VI & $100 \mathrm{mg} / \mathrm{kg})$ & $3.67 \pm 1.23^{c}$ & $1.00 \pm 0.37^{c}$ & 90.0 \\
\hline
\end{tabular}

Values are expressed as mean \pm S.E.M $(n=5)$; values with different superscripts along a column are statistically different $(p<0.05)$.

Table 3: Effect of ethanolic extract of Aristolochia ringens stem bark on castor-oil induced enteropooling in rats

\begin{tabular}{|c|c|c|c|c|c|}
\hline Group & Treatment & $\begin{array}{l}\text { Weight of } \\
\text { intestinal content } \\
\text { (g) }\end{array}$ & $\begin{array}{l}\text { Volume } \\
\text { intestinal } \\
(\mathrm{ml}) \\
\end{array}$ & $\begin{array}{r}\text { of } \\
\text { fluid }\end{array}$ & $\begin{array}{l}\text { Percentage } \\
\text { inhibition }\end{array}$ \\
\hline$I$ & Distilled water $(1 \mathrm{ml})$ & $2.87 \pm 0.28^{b c}$ & $1.50 \pm 0.30^{b c}$ & & -- \\
\hline II & DMSO (1 ml) & $4.47 \pm 0.22^{a}$ & $2.67 \pm 0.09^{a}$ & & -- \\
\hline III & Loperamide (2.5 mg/kg) & $3.03 \pm 0.07^{b c}$ & $1.60 \pm 0.26^{b c}$ & & 40.0 \\
\hline IV & $25 \mathrm{mg} / \mathrm{kg}$ & $3.57 \pm 0.23^{b}$ & $1.80 \pm 0.06^{b}$ & & 32.5 \\
\hline $\mathbf{v}$ & $50 \mathrm{mg} / \mathrm{kg}$ & $3.30 \pm 0.12^{b c}$ & $1.53 \pm 0.15^{b c}$ & & 42.5 \\
\hline VI & $100 \mathrm{mg} / \mathrm{kg}$ & $2.70 \pm 0.31^{c}$ & $1.03 \pm 0.12^{c}$ & & 61.3 \\
\hline
\end{tabular}

Values are expressed as mean \pm S.E.M $(n=5)$; values with different superscripts along a column are statistically different $(p<0.05)$. 
Fountain Journal of Natural and Applied Sciences 2018; 7(1): 20-28

Table 4: Effect of ethanolic extract of Aristolochia ringens stem bark on the intestinal transit of charcoal meal in rats

\begin{tabular}{llll}
\hline Group & Treatment & $\begin{array}{l}\text { Distance travelled by } \\
\text { charcoal }(\mathrm{cm})\end{array}$ & $\begin{array}{l}\text { Percentage } \\
\text { inhibition }\end{array}$ \\
\hline I & Distilled water & $28.83 \pm 0.83^{\mathrm{bc}}$ & -- \\
II & DMSO $(1 \mathrm{ml})$ & $45.83 \pm 2.17^{\mathrm{a}}$ & -- \\
III & Loperamide $(2.5 \mathrm{mg} / \mathrm{kg})$ & $28.67 \pm 2.68^{\mathrm{bc}}$ & 37.4 \\
IV & $25 \mathrm{mg} / \mathrm{kg}$ & $31.50 \pm 1.50^{\mathrm{b}}$ & 31.3 \\
V & $50 \mathrm{mg} / \mathrm{kg}$ & $30.833 \pm 0.60^{\mathrm{b}}$ & 32.7 \\
VI & $100 \mathrm{mg} / \mathrm{kg}$ & $25.17 \pm 0.17^{\mathrm{c}}$ & 45.0 \\
\hline
\end{tabular}

Values are expressed as mean \pm S.E.M $(n=5)$; values with different superscripts along a column are statistically different $(p<0.05)$.
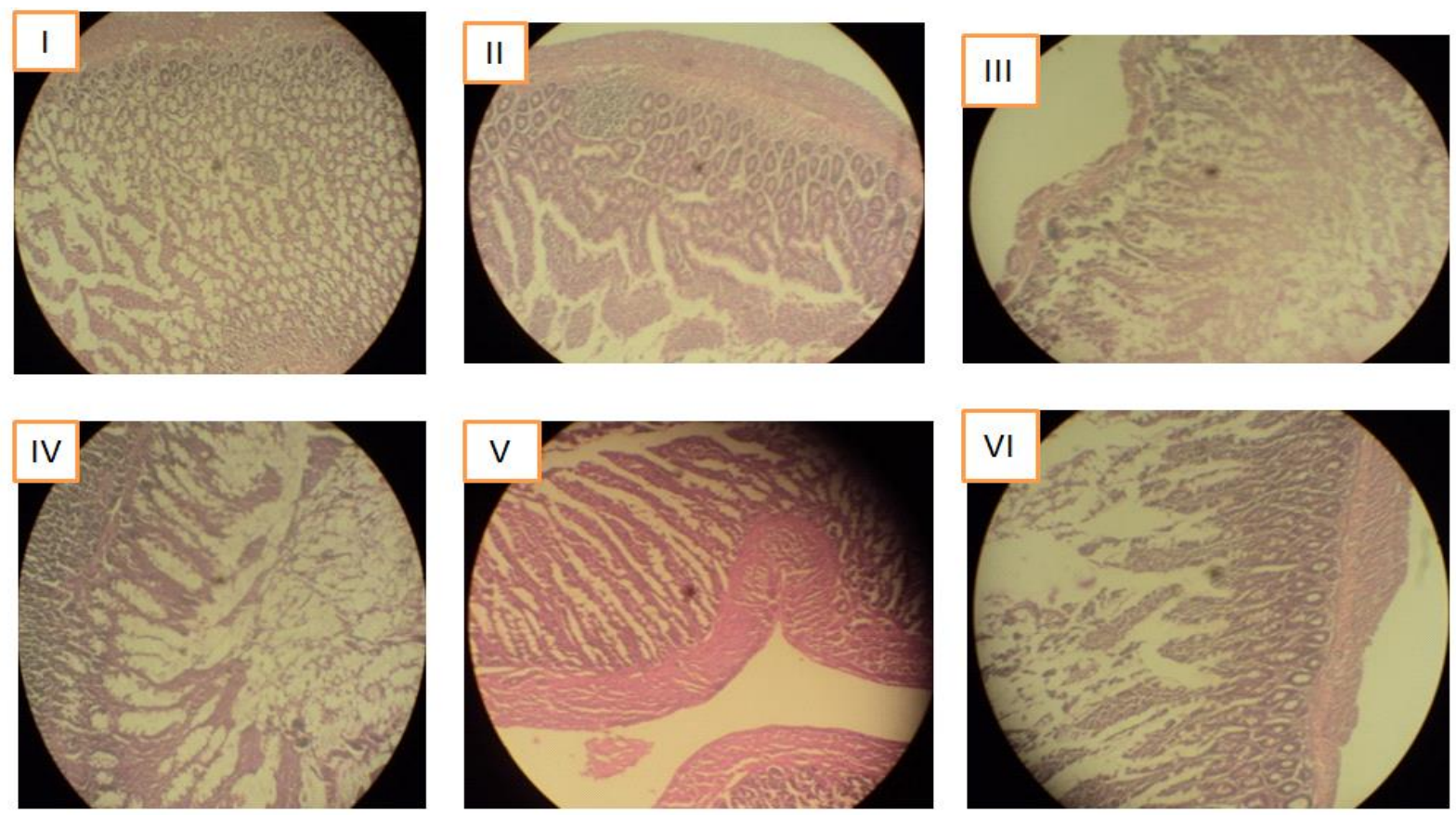

Plate 1: Photomicrographs of small intestine of castor oil-induced diarrhoeal rats orally administered $1 \mathrm{ml}$ of distilled water (I), DMSO (II), loperamide at $2.5 \mathrm{mg} / \mathrm{kg} \mathrm{b.} \mathrm{wt} \mathrm{(III)} \mathrm{and} \mathrm{Aristolochia} \mathrm{ringens} \mathrm{at} 25 \mathrm{mg} / \mathrm{kg}$ b. wt (IV), $50 \mathrm{mg} / \mathrm{kg}$ b. wt (V) and $100 \mathrm{mg} / \mathrm{kg} \mathrm{b.} \mathrm{wt} \mathrm{(VI)}$

\section{Discussion}

Phytochemicals are compounds found in any part of a plant that exhibit potentials for modulating biochemical processes in a manner favourable for the prevention and management of diseases. The use of herbal remedies in the treatment of diarrhoea is a common practice worldwide. A number of medicinal plants have been reported to be effective against diarrhoea and dysentery (Rouf et al., 2003; Gerald et al., 2007). However, the medicinal value of any plant lies in its constituent phytochemicals. The phytoconstituents detected in Aristolochia ringens: 
alkaloids, tannins, flavonoids, cardiac glycosides and phenolics (Table 1) are regarded as important bioactive compounds (Edeoga et al., 2005) and have been indicated as essential in the treatment of diarrhoea (Kumar et al., 2010). The array of observed constituents is in agreement with observations from previous qualitative (Fasola et al., 2015) and quantitative (Aigbe et al., 2017) phytochemical screening of Aristolochia rigens stem bark.

Castor oil is a triacylglycerol with a high content of the unsaturated fatty acid ricinoleic acid (Rahman et al., 2013). About $90 \%$ of ricinoleate in castor oil take part in causing diarrhoea (Mckeon et al., 1999). When castor oil is orally ingested as used in this experiment, ricinoleic acid is released by lipases in the intestinal lumen, and considerable amounts of ricinoleic acid are absorbed in the intestine (Watson and Gordon, 1962). With the presence of ricinoleate in small intestine, the peristaltic activity of small intestine increases as a result of change in the intestinal permeability to $\mathrm{Na}^{+}$and $\mathrm{Cl}^{-}$(Palombo, 2006), the normal fluid absorption is reduced and the net mucosal secretion is increased (Meite et al., 2009). Recinoleate also stimulates the secretion of endogenous prostaglandins which also stimulate increased secretion into the intestinal lumen and increase intestinal motility (Lakshminarayan et al., 2011). It has been shown that the laxative effect of ricinoleic acid present in castor oil is due to the induction of contraction of intestinal smooth muscle which is mediated by activation of EP3 receptors on intestinal smooth-muscle leading to increased intestinal motility (Brijesh et al., 2009; Rajput et al., 2015). These give the basis for the persistent diarrhoea in animals administered with castor oil.

The results of this study revealed that the ethanolic extract of Aristolochia ringens stem bark produced statistically significant reduction in diarrhoea and related gastrointestinal anomalies (such as intestinal accumulations and abnormal intestinal transit). These effects were found to be comparable to that of loperamide; a drug widely employed against diarrhoeal disorders. The antidiarrhoeal activity of the plant is concentrationdependent as seen in Tables 2-4. The highest dosage (100 mg/kg body weight) used exhibited a better action than the positive control drug loperamide.
Most anti-diarrhoeal agents are known to act through any or a combination of any of three mechanisms: increasing the water and $\mathrm{NaCl}$ reabsorption; reducing mucosal secretion; and inhibition of prostaglandin release from intestinal mucosa, thereby reducing the exacerbated intestinal motility (Qnais et al., 2007). The antidiarrhoeal effect of the ethanolic extract of $A$. ringens can be adduced to any of the above mechanisms due to its array of phytochemical constituents. Flavonoids and alkaloids contained in the plant are known for inhibiting the release of autacoids and prostaglandins, thereby inhibiting secretion induced by castor oil (Table 3) (Veiga et al., 2001) and the inhibitors of prostaglandin synthesis are known to ameliorate diarrhoea by ameliorating the intestinal motility (Table 4) (Sunill et al., 2001). The extract may increase the reabsorption of water and electrolytes by decreasing intestinal motility leading to the reversal of castor oil-induced intestinal fluid accumulation (Qnais et al., 2007). This is supported by the observation that the intestinal motility was significantly reduced in treated animals compared with control (Table 4).

Tannins (which are one of the phytochemicals identified in the extract) are known to possess antisecretory potential which they effect by acting locally on the gut wall to inhibit intestinal motility (Kumar et al. 2010). Tannins form protein tannates which reduce mucosal secretion and make the intestinal mucus resistant to chemical alteration (Havagiray et al., 2004). Phenolics have also been shown to prevent the increase in colonic motility through receptors in the proximal colon and the distal colon. The site and number of hydroxyl groups on the phenol group are thought to be related to their relative toxicity to microorganisms (Daswani et al., 2010).

Thus, the ethanolic extract of $A$. ringens stem bark might have effected its antidiarrhoeal effect (Table 2) by directly inhibiting mucosal secretion (Table 3) or through the amelioration of the increased intestinal peristalsis or motility (Table 4) associated with diarrhoea.

Histopathological examination of the small intestine suggests that the effect of castor oil on the intestine in its induction of diarrhoea can be 
Fountain Journal of Natural and Applied Sciences 2018; 7(1): 20-28

described as functional disturbances without conspicuous structural derangement. It further suggests that the ethanolic extract of $A$ ringen stem back does not compromise the intestinal integrity of the treated animals. This is evident in the similarly intact intestinal histology of the normal, castor oilinduced untreated (DMSO), loperamide and $A$. ringens stem bark-treated groups (Plate 1)

\section{Conclusion}

It can therefore be concluded that the ethanolic extract of the stem bark of Aristolochia ringens contains phytochemicals with antidiarrhoeal potentials that can be explored in the development of a viable antidiarrhoeal drug. This substantiates the use of the stem bark as an antidiarrhoeal and antidysentery agent by Traditional medical practitioners. Furthermore, it has been shown that castor oil and ethanolic extract of Aristolochia ringens stem bark do not affect the structural architecture of the small intestine.

\section{References}

Aigbe, F. R., Adeyemi, O. O., \& Sofidiya, M. O. (2014). The aqueous root extract of Aristolochia ringens (Vahl.) inhibits chemically-induced inflammation in rodents. Pakistan Journal of Pharmaceutical Science, 27 (6), 1885-1889.

Aigbe, F. R., Munavvar, A. S. Z., Rathore, H., Eseyin, O., Pei, Y. P., Akhtar, S., Chohan, A., Jin, H., Khoo, J., Tan, S., Lazhari, M., Afzar, S., Ahmed, F., Adeyemi, O. O., \& Johns, E. J. (2017) Alterations of haemodynamic parameters in spontaneously hypertensive rats by Aristolochia ringens Vahl. (Aristolochiaceae). Journal of Traditional and Complementary Medicine. doi: 10.1016/j.jtcme.2017.02.006

Alam, N.H., \& Ashraf, H. (2003). Treatment of infectious diarrhoea in children. Paediatric Drugs, 5,151-65.

Brijesh, S., Daswani, P., Tetali, P., Antia, N., \& Birdi, T. (2009) Studies on the antidiarrhoeal activity of Aegle marmelos unripe fruit: Validating its traditional usage. BMC Complementary and Alternative Medicine, 9(47), 1-12.

Daswani P.D., Brijesh S., Tetali P., Antia N. H., \& Birdi T.J. (2010). Antidiarrhoeal activity of Zingiber officinale (Rosc.). Current Science, 98(2), 222229.

Edeoga, H. O., Okwu, D. E., \& Mbaebie, B. O. (2005). Phytochemical constituents of some Nigerian medicinal plants. African Journal of Biotechnology, 4 (7), 685-688.

Fasola, T.R., Oluwole, M. E., Obatayo, O., \& Obayagbo, S.E. (2015). The antimicrobial potential and phytochemical composition of Aristolochia ringens Vahl. Advances in Life Science and Technology, 29, 5-12.

Gerald N.T., Jules, R. K., Omen, B. N., \& Dontien G. (2007). Antimicrobial activities of Emilla coccinea (Sims) G.Don extracts. Journal of Ethnopharmacology, 112, 283-287.

Guerrant, R. L., Van Gilder, T., \& Steiner, T.S. (2001). Practice guidelines for the management of infectious diarrhoea. Clinical Infectious Diseases, 32,331-351.

Havagiray, R., Ramesh, C., \& Sadhna, K. (2004). Study of antidiarrhoeal activity of Calotropis gigantean in experimental animals. Journal of Pharmaceutical Sciences, 7, 70-75.

Joy, P. P., Thomas, J., Mathew, S. \& Skaria, B. P. (2001). Medicinal Plants. Tropical Horticulture Vol. 2. (eds. Bose, T. K., Kabir, J., Das, P. and Joy, P.P.). Naya Prokash, Calcutta, 449-632.

Krause, W. J. (2001). The art of examining and interpreting histologic preparations. A student handbook. Partheton Publishing Group, UK. 9- 10.

Kumar, R., Sharma, R., Bairwa, K., Roy, R., \& Kumar, A. (2010) Pharmacological review on natural antidiarrhoeal agents. Der Pharma Chemica, 2, 6693.

Lakshminarayan, M., Shivkumar, H., Rimaben, P., \& Bhargava, V.K. (2011). Antidiarrhoeal activity of leaf extract of Moringa oleifera in experimentally induced diarrhoea in rats. International Journal of Phytomedicine, 2011; 3: 68-74.

Liu, L., Johnson, H. L., Cousens, S., Perin. J., Scott, S., \& Lawn, J.E. (2012). Global, regional, and national causes of child mortality: an updated systematic analysis for 2010 with time trends since 2000. Lancet, 379, 2151-61.

Mckeon, T. A., Lin, J. J., \& Stafford, A. E. (1999). Biosynthesis of ricinoleate in castor oil. Advanced Experimental and Medical Biology, 464, 37-47. 
Meite, S., N'guessan, J. D., Bahi, C., Yapi, H.F., Djaman, A.J., \& Guina, F.G. (2009). Antidiarrhoeal activity of the ethyl acetate extract of Morinda morindoides in rats. Tropical Journal of Pharmaceutical Research, 8(3): 210-207.

Minari, J. B., \& Idris, M. A. (2015). Forensic and Pharmacognostic Study of Aristolochia ringens Stem. Journal of Forensic Research, 6, 257. doi: $10.4172 / 2157-7145.1000257$

National Institute of Health. (1996). Revised Guide for the Care and Use of Laboratory Animals Guide, 25(28). The National Academies Press 500 Fifth Street, NW Box 285 Washington, DC 20055.

Nigerian Natural Medicine Development Agency (NNMDA). (2008). Medicinal plants in South-East Nigeria. 1: 21.

Njoku, O.V., \& Obi, C. (2009). Phytochemical constituents of some selected medicinal plants. African Journal of Pure and Applied Chemistry, 3(11), 228-233

Njume, C., Afolayan, A. J., Samie, A., \& Ndip, R.N. (2011). Inhibitory and bactericidal potential of crude acetone extracts of Combretum molle (Combretaceae) against drug-resistant strains of Helicobacter pylori. Journal of Health, Population and Nutrition, 29, 438-445.

Ojewole, J.A.O., Awe, E.O., \& Chiwororo, W.D.H. (2008). Antidiarrhoeal activity of Psidium guajava Linn. (Myrtaceae) leaf aqueous extract in rodents. Journal of Smooth Muscle Research, 44, 195-207. Olabanji, S.O., Omobuwajo, O.R., Ceccato, D., Adebajo, A.C., Buoso, M.C., \& Moschini, G. (2008). Accelerator-based analytical technique in the study of some anti-diabetic medicinal plants of Nigeria. Nuclear Instruments and Methods in Physics Research B, 266, 2387-2390.

Palombo, E. A. (2006). Phytochemicals from traditional medicinal plants used in the treatment of diarrhoea: Modes of action and effects on intestinal function. Phytotherapy Research, 20, 717-724.
Qnais, E. Y., Elokda, A. S., Abu Ghalyun, Y. Y., \& Abdulla, F. A. (2007). Antidiarrhoeal Activity of the aqueous extract of Punica granatum (Pomegranate) Peels. Pharmaceutical Biology, 45(9), 715-720.

Rahman, M. K., Barua, S., Islam, M. F., Islam, M. R., Sayeed, M. A., Parvin, M. S., \& Islam, M. E. (2013). Studies on the anti-diarrhoeal properties of leaf extract of Desmodium puchellum. Asian Pacific Journal of Tropical Biomedicine, 3(8), 639-643.

Rajput, R. T., Gohil, K. J., Kumar S., \& Kumar S. (2015). Development of anti-diarrhoeal polyherbal formulation "Antitrots". American Journal of Phytomedicine and Clinical Therapeutics, 3(03), 257-263.

Rouf, A. S., Islam, M. S., \& Rahman, M.T. (2003).

Evaluation of antidiarrhoeal activity of Rumex maritimus roots. Journal of Ethnopharmacology, 84, 307-310.

Sulyman, A. O., Akolade, J. O., Sabiu, S. A., Aladodo, R. A., \& Muritala, H. F. (2016). Antidiabetic potentials of ethanolic extract of Aristolochia ringens (Vahl.) roots. Journal of Ethnopharmacology, 182, 122-128.

Sunil, B., Bedi, K., Singla, A., \& Johri, R. (2001). Antidiarrhoeal activity of piperine in mice. Planta Medica, 67, 284-287.

United Nations Children's Fund (UNICEF). (2016). One is too many: Ending child deaths from pneumonia and diarrhoea. Data and Analytics, Division of Data, Research and Policy and Health Section, Programme Division 3 United Nations Plaza New York, NY 10017, USA.

Veiga, V. F., Zunino, L., Calixto, J. O. B., Patitucci, M. L., \& Pinto, A. N. C. (2001). Phytochemical and antioedematogenic studies of commercial copaiba oils available in Brazil. Phytotherapy Research, 15, 476-480.

Watson, W.C., \& Gordon, R.S. (1962). Studies on the digestion, absorption and metabolism of castor oil. Biochemistry and Pharmacology, 11, 229-236. 